\title{
THE FACTORS OF BULLYING AND CHARACTER EDUCATION ON TEENAGERS
}

\author{
Syifa Shafira Azzahra ${ }^{1}$, Maria Ardiningsih Pandin ${ }^{2}$, Moses Glorino Rumambo Pandin ${ }^{1}$ \\ ${ }^{1}$ Faculty of Humanities, Universitas Airlangga, Surabaya, Indonesia \\ ${ }^{2}$ Sekolah Menengah Atas Negeri 16 Surabaya, Indonesia
}

\begin{abstract}
The research objective was to determine the problem of bullying in teenagers. The method used is a qualitative approach with literature study methods and a quantitative approach with the e-survey method. The results showed that bullying was rife in the school environment with teenagers aged 12-15. Verbal bullying occurs the most because it is the easiest to do. Bullying occurs with a group of people against one person because of peer influence. Family factors, school, the influence of friends, environmental conditions, and television shows influence bullying. Character Education can help overcome bullying in teenagers because it teaches the value of virtue in daily activities if given early and not during teenager. The conclusion found in this activity is that teenagers can become bullies because of family, school, peer influence, social conditions, and television broadcasts. Character Education is more effective if it is implemented since early childhood education and all relevant stakeholders must be actively involved in providing the Character Education.
\end{abstract}

Keywords: bullying, character, education, teenager, family

\section{INTRODUCTION}

Bullying is an endless case as the number continues to increase. Bullies are dominated by teenagers aged 12-15 years. Teens who are looking for identity must experience or commit bullying. It happens because Character Education has not been implemented maximum so that teenagers commit behavioral deviations.

Bullying is an act carried out by a person or group of people to make someone ashamed and suffer (Sari and Azwar, 2017: 334). The Indonesian Child Protection Commission (KPAI) stated that until 2016 there were 1,106 incidents of bullying in schools, with 676 cases of children as victims and 430 children as perpetrators (Lika, 2019: 309). This number continues to grow every year. 
Andrew Mellor (in Hikmah and Suhanda, 2017: 43) explains that there are four types of bullying: (1) Physical bullying (kicking, hitting, choking, pinching, etc.); (2) Verbal Bullying (taunting, slandering, terrorizing, etc.). Verbal bullying is the easiest to do (Suciartini and Sumartini, 2018: 154); (3) Psychic bullying (lying, spreading hoaxes, humiliating and isolating someone, etc.); (4) Cyberbullying (making posts in the form of text, images, or videos, to intimidate, frighten, etc.).

Another bullying is sexual, namely catcalling, vulgar movements, and acts that contain pornography (Laudy Gracivia, 2019). Darmawan (2017: 256) says that bullying occurs with a group of people against someone. Due to friends' influence, such as provocation from a group of friends to bully within-group so that they feel that someone who is forced deserves to be treated like that (Theodore and Sudardji, 2019: 69).

Some people tend to let it go when there is bullying because they are considered just playing around (Janitra and Prasanti, 2017: 24). Bullying can hurt the victim physically and mentally, namely feelings of disrespect, depression, and even suicidal tendencies (Zakiyah, Humaedi, and Santosa, 2017: 325). A bully becomes feeling unworthy of life, anxious, and has the potential to isolate himself from the environment, injure himself, and even commit suicide (Faizah and Amna, 2017: 79). According to Prasada (2019: 166), teenagers need to understand that bullying means taking someone's right to grow and develop and avoid violence.

Character Education is learning about etiquette to foster the ability to weigh good and bad decisions and goodness in everyday life. The importance of character education is made clear by the 2003 National Learning Mechanism Act concerning State Teaching Targets, namely intelligence, character, and virtue (KPAI, 2014). 
Based on the context of the problems previously presented, the questions in this study are: What are the factors that cause teenagers to become bullies?; Is there a law to prosecute teen bullies? And How can Character Education solve cases of youth bullying? This study aims to determine the purpose of bullying, the types of bullying, the factors that cause teenagers to become bullies, the reasons for bullying should not occur, the law to prosecute teen bullies, and how character education can solve cases of teen bullying.

\section{METHOD}

The method used to answer the problem is a qualitative approach with the literature study method, namely collecting literature materials, and a quantitative approach with the esurvey method, namely by creating a Google Form questionnaire.

The primary qualitative data used to answer the problem are ten journal articles about bullying with the 2017-2019 publication year. Secondary data to support preliminary data are two news articles about bullying taken from the internet. This primary data is added by data from 50 respondents regarding bullying in teenagers.

The analysis technique used to answer the problems in this proposal is descriptive analysis, which is to collect material in the form of public response to bullying by giving some questions that the respondent must answer.

The data collection techniques are using literature and survey studies. Researcher's first technique: a) determine the research problem; b) looking for literature sources related to research problems; c) read the literature sources that have been searched; and d) cite information from the literature source. 
The procedure for the e-survey data collection technique is a) to determine the research problem; b) determine the questions to be asked in the survey; c) determine the maximum target respondents; d) enter a list of questions into Google Form; e) waiting for the maximum target respondents to be reached; e) perform data processing on the survey results; f) adding survey results to the research results

\section{.RESULTS}

Based on the processing of respondent data obtained through a survey with Google Form involving 50 respondents, it shows the following:

Have you ever been bullied in your life? Based on the survey results, 38\% (19 respondents) have been bullied, 32\% (16 respondents) have never been bullied, and 30\% (15 respondents) answered maybe. Based on the survey results, 78\% (39 respondents) had seen their friends bullied at school, 4\% (2 respondents) never had, and 18\% (9 respondents) answered maybe. Based on the survey results regarding the community's response to Character Education's implementation only for bullies, 10\% (5 respondents) considered it valid, and 90\% (45 respondents) thought it was not valid. Based on the survey results regarding knowledge of the legal basis for teen bullies, 24\% (12 respondents) felt there was a legal basis for prosecuting teen bullies, 22\% (11 respondents) felt there was no legal basis for prosecuting teen bullies, and 54\% (27 respondents) were doubtful. (Table 1).

Table 1: Survey Results on bullying and Character education

\begin{tabular}{lccc}
\hline \multicolumn{1}{c}{ Question } & Yes & No & Maybe \\
\hline Once bullied at school & 38 & 32 & 30 \\
I never witnessed a friend being bullied & 78 & 4 & 18 \\
Is there a legal basis for prosecuting teen bullies & 24 & 22 & 54 \\
Is character education only for bullies & 10 & 90 & 0
\end{tabular}


Is character education sufficient as a solution to overcoming bullying for a teenager?

The following three questions are based on the survey results, 58\% (29 respondents) experienced verbal bullying, 10\% (5 respondents) experienced psychological bullying, $12 \%$ (6 respondents) experienced physical bullying, 14\% (7 respondents) experienced cyber bullying, and $6 \%$ (3 respondents) experienced sexual abuse; Based on the survey results, $40 \%$ (20 respondents) considered Character Education sufficient as a solution to dealing with teenage bullying with additional information, such as "must be applied seriously" and "must be improved again", 58\% (29 respondents) considered it not and with additional information, such as "there must be a sanction that creates a deterrent effect on the perpetrator", $2 \%$ (1 respondent) answered neutral; and based on the survey results, $2 \%$ (1 respondent) answered that Character Education was applied when the child was not yet in school, while the rest answered with a higher education level, namely 44\% (22 respondents) answered "Kindergarten", 50\% (25 respondents) answered "primary school", 4\% (2 respondents) answered "Junior high school"; and based on the survey results, 36\% (18 respondents) responded to "parents" and 64\% (32 respondents) responded varied, such as "parents and teachers", "parents, teachers, lecturers, and the public", and "all people who are close to the child's environment. (Table 2).

Table 2. Type of bullying, the timing of giving, and Stakeholders involved

\begin{tabular}{|c|c|c|c|c|c|}
\hline \multirow{4}{*}{$\begin{array}{c}\text { The Type of experienced } \\
\text { bullying }\end{array}$} & \multicolumn{5}{|c|}{ Bullying } \\
\hline & Physical & Verbal & Psychic & Cyber & sexual \\
\hline & 12 & 58 & 10 & 14 & 6 \\
\hline & \multicolumn{5}{|c|}{ Level of education } \\
\hline \multirow{3}{*}{$\begin{array}{l}\text { Since when should character } \\
\text { education be implemented }\end{array}$} & & & prim & \multirow{2}{*}{\multicolumn{2}{|c|}{$\begin{array}{l}\text { Junior High } \\
\text { School }\end{array}$}} \\
\hline & pre-kindergarten & Kindergarten & $\begin{array}{c}\text { ary } \\
\text { scho } \\
\text { ol }\end{array}$ & & \\
\hline & 2 & 44 & 50 & \multicolumn{2}{|c|}{4} \\
\hline
\end{tabular}




\begin{tabular}{ccc}
\hline & \multicolumn{2}{c}{ The one who gave character education } \\
\hline $\begin{array}{c}\text { Who should provide character } \\
\text { education }\end{array}$ & Parents & Variations of Answers \\
\cline { 2 - 3 } & 36 & 64 \\
\hline
\end{tabular}

\section{DISCUSSION}

According to Zakiyah, Humaedi, and Santosa (2017: 327), five factors cause teenagers to become bullies: (1) Family: when teenagers see violence at home, they can imitate this action. If parents are accustomed to punishing children without reason, it is the trigger for bullying (Janitra and Prasanti, 2017: 31); (2) School: Schools underestimate and tend to ignore when bullying occurs, then bullying develops rapidly; (3) Influence of friends: A person becomes a bully because he wants to be considered influential and the existence of a group norm that a person being bullied by many people is worthy of being forced; (4) Environmental conditions: environmental conditions affect a person to become a bully, such as a teenager born to a family that is less capable of committing bullying; (5) Television: Television shows can have an impact on teenagers into imitating fight scenes in films.

Bullying includes a criminal act as in Article 7 (1) of Law Number 11 of 2012 concerning Child Justice, namely, bullying can be subject to significant criminal penalties: reprimand, conditional punishment, job upgrading, guidance in institutions, and jail time (Ichsan and Sambas, 2018: 378). According to Article 45 of the Criminal Code, people who are less than 16 years old, if they are deemed incapable of appearing before the court, can be returned to their parents or guardians without any punishment or given to the government, and the crime has not passed two years. However, imprisonment can be enforced, with the maximum sentence being reduced by one-third (Prasada, 2019: 171).

Based on the survey results regarding the community's response to teen bullies who cannot be jailed, bullies can be given Character Education, Warning Letters (SP) from 
the school, and psychological therapy. Through character education that seeks to instill virtue, it is hoped that bullying cases in adolescent circles can be resolved (KPAI, 2014).

Bullying is still rife in schools with teenage victims aged 12-15 years. The survey results proved that 19 respondents (38\%) had been bullied, and 39 respondents ( $78 \%)$ had seen their schoolmates being forced. There are five types of bullying: physical, verbal, psychological, cyber, and sexual bullying. Verbal bullying is the easiest to do. The survey results proved that verbal bullying was experienced by 29 respondents $(58 \%)$.

Bullying occurs with a group of people against one person because of peer influence. Based on the results obtained from reading the literature, teenagers can become bullies because of family, school, peer influence, social conditions, and television broadcasts.

Character education is expected to be a solution to overcome bullying cases in teenager environments because of the application of virtue values in daily activities. In applying Character Education optimally, the survey proves that 45 respondents (90\%) do not agree that Character Education is only for bullies. Besides, 29 respondents (58\%) disagreed that only Character Education was given to teenagers. Then, as many as 25 respondents (50\%) agreed that Character Education was implemented when teenagers were in elementary school, and 32 respondents (64\%) answered that all parties should provide character Education: parents, teachers, and people around them.

\section{CONCLUSION}

Teenagers can become bullies because of family factors, school, environmental conditions, and television shows. Teenage bullying should not occur because it takes away someone's right to grow and develop, including being safe from violent threats. Bullying can be charged under Article 7 (1) of Law Number 11 of 2012 concerning the Child Justice 
Mechanism, namely bullies can be charged with primary criminal convictions: reprimand, conditional punishment, job upgrading, guidance in institutions, and imprisonment. However, bullies aged 12-15 years who cannot be jailed can be given Character, Warning Letters (SP), and psychological therapy.

Character Education teaches etiquette to weigh good and bad decisions and show virtue. Still, it is not effective if it is only applied to bullies so that Character Education should be given from an early age. All parties must be involved in providing the Character Education.

\section{REFERENCES}

Cnnindonesia.com. (2019, 11 April). Mengenal Jenis-Jenis Bullying atau Perundungan. Diakses pada 10 Maret 2020, dari https://www.cnnindonesia.com/gayahidup/20190411135109-260-385320/mengenal-jenis-jenis-bullying-atauperundungan.

Darmawan. (2017). Fenomena Bullying (Perisakan) di Lingkungan Sekolah. Jurnal Keepi, l(2): $253-262$.

Faizah, F. \& Amna, Z. (2017). Bullying dan Kesehatan Mental pada Remaja Sekolah Menengah Atas di Banda Aceh. Gender Equality: International Journal of Child and Gender Studies, 3(1): 77-84.

Hikmah, E. \& Suhanda, P. (2017). Pengaruh Terapi Asertif terhadap Kecenderungan Perilaku Bullying pada Siswa SMPN 1 Rajeg Kabupaten Tangerang. Jurnal Medikes, 4(1): 42-49.

Ichsan, T. \& Sambas, N. (2018). Penegakan Hukum Terhadap Pelaku Tindak Pidana Bullying Berdasarkan Undang-Undang Nomor 35 Tahun 2014 Perubahan atas Undang-Undang Nomor 23 Tahun 2002 Tentang Perlindungan Anak JO. UndangUndang Nomor 11 Tahun 2012 Tentang Sistem Peradilan Pidana Anak. Prosiding Ilmu Hukum, 4(1): 373-380.

Janitra, P.A. \& Prasanti, D. (2017). Komunikasi Keluarga dalam Pencegahan Perilaku Bullying Bagi Anak. Jurnal Ilmu Sosial Mamangan, 6(1): 23-33.

Kpai.go.id. (2014, 16 Oktober). KPAI: Kasus Bullying dan Pendidikan Karakter. Diakses pada 10 Maret 2020, dari https://www.kpai.go.id/berita/kpai-kasus-bullying-danpendidikan-karakter.

Lika. (2019). Pelatihan Empati Sebagai Upaya Mengurangi Perilaku Perundungan pada Siswa SMP. Persona: Jurnal Psikologi Indonesia, 8(2): 308-324.

Prasada, D. K. (2019). Pengaturan Delik Pidana Terkait Tindakan Bullying Bagi Anak di Bawah Umur. Acta Comitas: Jurnal Hukum Kenotariatan, 4(2): 165-176.

Sari, Y. P. \& Azwar, W. (2017). Fenomena Bullying Siswa: Studi Tentang Motif Perilaku Bullying Siswa Di SMP Negeri 01 Painan, Sumatera Barat. Ijtimaiyya: Jurnal Pengembangan Masyarakat Islam, 10(2): 333-367. 
Suciartini, N. N. A. \& Sumartini, N. L. P. U. (2018). Verbal Bullying dalam Media Sosial. Jurnal Pendidikan Bahasa Indonesia, 6(2): 153-171.

Theodore, W. \& Sudarji, S. (2019). Faktor-Faktor Perilaku Perundungan pada Pelajar Usia Remaja di Jakarta. Jurnal Psibernetika, 12(2): 67-79.

Zakiyah, E. Z., Humaedi, S., \& Santoso, M. B. (2017). Faktor Yang Mempengaruhi Remaja dalam Melakukan Bullying. Jurnal Penelitian \& PPM, 4(2): 129-389. 